\title{
Starch and Microbial $\alpha$-Amylases: From Concepts to Biotechnological Applications
}

\author{
Amira El-Fallal, Mohammed Abou Dobara, Ahmed El-Sayed and Noha Omar \\ Additional information is available at the end of the chapter
}

http://dx.doi.org/10.5772/51571

\section{Introduction}

Starch is a polymer of glucose linked to one another through the $\mathrm{C} 1$ oxygen, known as the glycosidic bond. Amylases are capable of digesting these glycosidic linkages found in starch. Amylases have been isolated from diversified sources including plants, animals, and microbes, where they play a dominant role in carbohydrate metabolism. In spite of the wide distribution of $\alpha$-amylase, microbial sources are used for the industrial production. This is due to their advantages such as cost effectiveness, consistency, less time and space required for production as well as ease of process modification and optimization.

In the present day scenario, $\alpha$-amylases have applications in all the industrial processes such as in food, detergents, textiles and paper industry, for the hydrolysis of starch. They can also be of potential use in the pharmaceutical and fine chemical industries. In this light, microbial $\alpha$-amylases have completely replaced chemical hydrolysis in the starch processing industry. Despite this, interest in new and improved $\alpha$-amylase is growing and consequently, the research is intensified as well to meet requirements set by specific applications.

\section{Starch}

Starch and starch-containing substrates are wide spread in nature and also in industrial praxis. They can predominantly find their application in many industrial processes.

\subsection{Sources and utilization}

Starch occurs mainly in the seeds, roots and tubers of higher plants. Some algae produce a similar reserve polysaccharide called phytoglycogen. Plants synthesize starch as a result of 
photosynthesis. It is synthesized in plastids as a storage compound for respiration during dark periods. It is also synthesized in amyloplasts found in tubers, seeds, and roots as a long-term storage compound. In these latter organelles, large amounts of starch accumulate as water-insoluble granules. The shape and diameter of these granules depend on the botanical origin. Regarding to commercial starch sources, the granule sizes range from 2-30 $\mu \mathrm{m}$ (maize starch) to 5-100 $\mu \mathrm{m}$ (potato starch) (Robyt, 1998). A variety of different enzymes are involved in the synthesis of starch. Sucrose is the starting point of starch synthesis. It is converted into the nucleotide sugar ADP-glucose that forms the actual starter molecule for starch formation. Subsequently, enzymes such as soluble starch synthase and branching enzyme synthesize the amylopectin and amylose molecules (Smith, 1999).

Starch-containing crops form an important constituent of the human diet. Besides the direct use of starch-containing plant parts as a food source, starch is harvested and chemically or enzymatically processed into a variety of different products such as starch hydrolysates, glucose syrups, fructose, starch or maltodextrin derivatives, or cyclodextrins. In spite of the large number of plants able to produce starch, only a few plants are important for industrial starch processing. The major industrial sources are maize, tapioca, potato, and wheat.

\subsection{Structure and properties}

Starch is a polymer of glucose linked to one another through the $\mathrm{C} 1$ oxygen by a glycosidic bond. This glycosidic bond is stable at high $\mathrm{pH}$ but hydrolyzes at low $\mathrm{pH}$. At the end of the polymeric chain, a latent aldehyde group is present. This group is known as the reducing end. Two types of glucose polymers are present in starch: (i) amylose and (ii) amylopectin. While amylopectin is soluble in water, amylose and the starch granule itself are insoluble in cold water.

Amylose is a linear polymer consisting of up to 6000 glucose units with $\alpha, 1-4$ glycosidic bonds (Fig. 1a.). The number of glucose residues, also indicated with the term DP (degree of polymerization), varies with the origin. The relative content of amylose and amylopectin varies with the source of starch. The average amylose content in most common starches, e.g. in barley, corn and potato, is 20-30\% (Marc et al., 2002).

Amylopectin consists of short $\alpha, 1-4$ linked linear chains of 10-60 glucose units and $\alpha, 1-6$ linked side chains with 15-45 glucose units (Fig. 1b.). The average number of branching points in amylopectin is $5 \%$ (Thompson, 2000), but varies with the botanical origin. The complete amylopectin molecule contains about 2000,000 glucose units, thereby being one of the largest molecules in nature (Marc et al., 2002). The most commonly accepted model of the structure of amylopectin is the cluster model, in which the side chains are ordered in clusters on the longer backbone chains (Bertoft, 2007; Thompson, 2000). In general, Zhu et al. (2011) suggested that the internal part of amylopectin is critical to the physical behavior of granular starch.

The diameter of starch granules ranges from 2 to $100 \mu \mathrm{m}$ (Whistler \& Daniel, 1985) depending on its source. The orientation of the starch chains is thought to be perpendicular 
to the granule surface (French, 1984). Native starch is partly crystalline. The crystallinity of native starch varies between 15 and $45 \%$ depending on the origin and pretreatment (French, 1984). According to the currently accepted concept, amylopectin forms the crystalline component whereas amylose exists mainly in the amorphous form (Hanashiro et al., 1996; Marc et al., 2002; Zobel, 1992). Structural studies have shown that native starch has crystalline polymorphism. In x-ray diffraction, cereal starch typically gives A-type patterns of monoclinic symmetry, and tuber starch gives B-type patterns of hexagonal symmetry (Gerard et al., 2000; Imberty et al., 1991). The crystal lattice of B-type starch contains more water molecules than the A- structures, which is proposed to be the reason for higher stability of the A- structure. Both structures' molecular conformations are practically identical. They have left-handed double helices with parallel strands. Double helices contain six glucose units per turn in each chain and the glucose units are in a chair conformation. With in the double helix, there are inter-chain but no intra-chain hydrogen bonds. In additional, parallelly packed double helices are connected through a hydrogen bonding network.

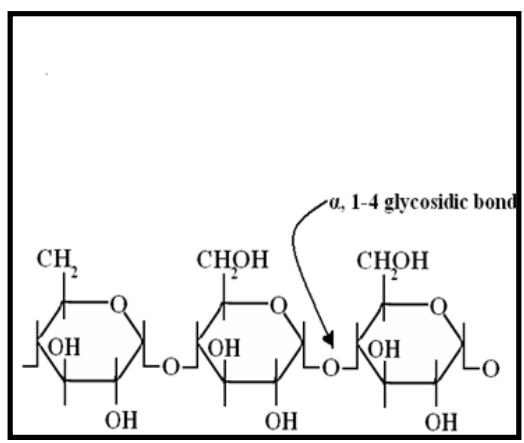

(a) amylose

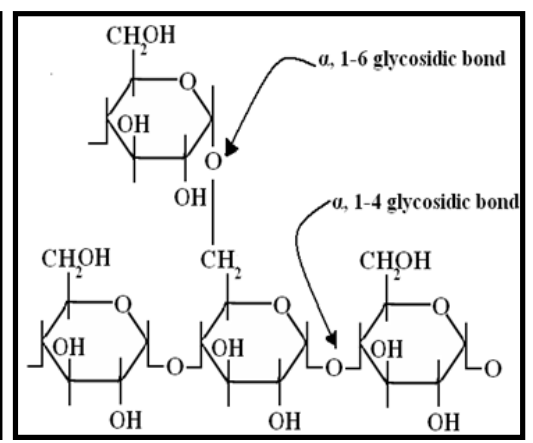

(b) amylopectin

Figure 1. Amylose and amylopectin chain structure

\section{Amylases}

Amylases are a class of enzymes that are capable of digesting these glycosidic linkages found in starches. Amylases can be derived from a variety of sources. They are present in all living organisms, but the enzymes vary in activity, specificity and requirements from species to species and even from tissue to tissue in the same organism. Raw-starch digesting amylases are produced by a variety of living organisms, ranging from microorganisms including fungi, yeast, and bacteria to plants and humans.

\subsection{Microbial sources of amylases}

Several amylase-producing bacteria, fungi and other microrganisms have been isolated and characterized over many decades. Bacteria and fungi secrete amylases outside their cells to carry out extra-cellular digestion. 
Among mold species producing high levels of amylase, those of Aspergillus niger, Aspergillus oryzae (Aunstrup, 1979), Thermomyces lanuginosus (Arnesen et al., 1998) and Penicillium expansum (Doyle et al., 1989) in addition to many species of the genus Mucor (Domsch et al., 1995; Petruccioli \& Federici, 1992; Zare-Maivan \& Shearer, 1988). It was reported that four species of Ganoderma mushrooms could produce relatively weak amylase in sawdust medium (Y.W. Wang \& Y. Wang, 1990). Amylolytic yeasts differ strongly with regard to amylase secretion and the extent of starch hydrolysis (De Mot et al., 1984a, 1984b). Strains of Filobasidiuim capsuligenum are capable of extensive starch hydrolysis (De Mot et al., 1984c; McCann\& Barnett, 1984).

Regarding to bacteria, Bacillus spp and the related genera produce a large variety of extracellular enzymes, of which amylases are of particular significance to the industry e.g., B. cereus (Rhodes et al., 1987), B. circulans (Siggens, 1987), B. subtilis (El-Banna et al., 2007), B. licheniformis (El-Banna et al., 2008) and Clostridium thermosulfurogenes (Hyun \& Zeikus, 1985a). Bacteria belonging mainly to the genus Bacillus have been widely used for the commercial production of thermostable $\alpha$-amylase (Tonkova, 2006). However, most of the Bacillus liquefying amylases, such as the enzymes from B. amyloliquefaciens and $B$. stearothermophilus have $\mathrm{pH}$ optima of between 5 and 7.5 (Yamamoto, 1988). Many alkaline amylases have been found in cultures of Bacillus sp. (Hayashi et al., 1988; Kim et al., 1995). This alkaline amylases are all of the saccharifying type, except for the enzymes from Bacillus sp. strain 707 (Kimura et al., 1988) and B. licheniformis TCRDC-B13 (P. Bajpai and P.K. Bajpai, 1989). Thermostable $\beta$-amylases have been isolated from Bacillus species (Shinke et al., 1974; Takasaki, 1976). Also, Lactobacillus plantarum strain A6 was selected for its ability to synthesize large amounts of extracellular $\alpha$-amylase (Giraud et al., 1991). Furthermore, a variety of ruminal bacteria exhibit the ability to utilize starch as a growth substrate and are present in the rumen in sufficient numbers to be of quantitative significance in the fermentation of this substrate. These species include Bacteroides ruminicola, Ruminobacter amylophilus, Butyrivibrio fibrisolvens, Selenomonas ruminantium, and Streptococcus bovis (Russell, 1984).

Genes encoding intracellular $\alpha$-amylases have been reported for Escherichia coli and Streptococcus bovis (Satoh et al., 1997; Whitehead \& Cotta, 1995). Although there has been some characterization of these activities, no clear physiological role for intracellular $\alpha$ amylase has been established for either E. coli or Streptococcus bovis. However, it is postulated that it plays an important role in rapid cell growth in Streptococcus bovis (Brooker \& McCarthy, 1997).

Many hyperthermophilic microorganisms possess starch-hydrolyzing enzymes in their genomes even though they live in environments where starch is rare (Sambrook et al., 1989). Among the polysaccharide-degrading enzymes of Thermotoga maritime described so far are two $\alpha$-amylases, one is an extracellular putative lipoprotein (AmyA) (Liebl et al., 1997) and one is located in the cytoplasm (AmyB) (Lim et al., 2003). Geobacillus thermoleovorans has been found to produce hyperthermostable, high maltose-forming and $\mathrm{Ca}^{2+}$ independent $\alpha$ amylase (Malhotra et al. 2000; Narang \& Satyanarayana 2001). Numerous 
hyperthermophilic Archaea, especially deep-sea Thermococcale and Sulfolobus species have been reported to produce $\alpha$-amylases (Leuschner and Antranikian, 1995; Sunna et al., 1997).

The industrial potential of high-maltose forming $\alpha$-amylases from Thermomonospora curvata (Collins et al., 1993) is limited by their moderate thermostability and $\mathrm{Ca}^{2+}$ requirement.

$\alpha$-Amylases are secreted by several species of Streptomyces, for example S. albus (Andrews \& Ward, 1987), S. griseus IMRU3570 (Vigal et al., 1991), S. thermocyaneoviolaceus (Hang et al., 1996). Gene encoding extracellular $\alpha$-amylase has been cloned from many Streptomyces species (Bahri \& Ward, 1990; Virolle et al., 1988). In addition, $\alpha$-amylase activity of Thermoactinomyces species was first reported by Kuo \& Hartman (1966). After that, several $\alpha$ amylases with different characters were found in other studies (Obi \& Odibo, 1984; Omar et al., 2011; Shimizu et al., 1978; Uguru et al., 1997). Within actinomycetes, available reports on $\beta$-amylase production are scanty and refer mainly to nonthermostable enzyme (Shinke et al., 1974).

\subsection{Amylases types}

Enzymes belonging to amylases, endoamylases and exoamylases, are able to hydrolyse starch. These enzymes are classified according to the manner in which the glycosidic bond is attacked. The starch degrading enzymes are found in the numerous glycoside hydrolase (GH) families (13, 14 and 15), mainly in GH family 13 (Coutinho \& Henrissat, 1999; Henrissat, 1991).

Endoamylases are able to cleave $\alpha, 1-4$ glycosidic bonds present in the inner part (endo-) of the amylose or amylopectin chain. $\alpha$-amylase (EC 3.2.1.1) is a well-known endoamylase. It is found in a wide variety of microorganisms, belonging to the Archaea as well as the Bacteria (Pandey et al., 2000). The end products of $\alpha$-amylase action are oligosaccharides with varying length with $\alpha$-configuration and $\alpha$-limit dextrins, which constitute branched oligosaccharides. $\alpha$-amylases are often divided into two categories according to the degree of hydrolysis of the substrate (Fukumoto \& Okada, 1963). Saccharifying $\alpha$-amylases hydrolyze 50 to $60 \%$ and liquefying $\alpha$-amylases cleave about 30 to $40 \%$ of the glycosidic linkages of starch.

Enzymes belonging to the second group, the exoamylases, either exclusively cleave $\alpha, 1-4$ glycosidic bonds such as $\beta$-amylase (EC 3.2.1.2) or cleave both $\alpha, 1-4$ and $\alpha, 1-6$ glycosidic bonds like amyloglucosidase or glucoamylase (EC 3.2.1.3) and $\alpha$-glucosidase (EC 3.2.1.20). Exoamylases act on the external glucose residues of amylose or amylopectin and thus produce only glucose (glucoamylase and $\alpha$-glucosidase), or maltose and $\beta$-limit dextrin. $\beta$-amylase and glucoamylase also convert the anomeric configuration of the liberated maltose from $\alpha$ to $\beta$. Glucoamylase and $\alpha$-glucosidase differ in their substrate preference: $\alpha$-glucosidase acts best on short maltooligosaccharides and liberates glucose with $\alpha$-configuration while glucoamylase hydrolyzes long-chain polysaccharides best. $\beta$ amylases and glucoamylases have also been found in a large variety of microorganisms (Pandey et al., 2000). 


\section{3. $\alpha$-amylases actions and structure}

\subsubsection{Mode of action}

In general, it is believed that $\alpha$-amylases are endo-acting amylases which hydrolyze $\alpha-(1-4)$ glycosidic bonds of the starch polymers internally. Several models for amylase action pattern have been proposed, such as the random action and the multiple attack action. Random action has also been referred to as a single attack or multi-chain attack action (Azhari \& Lotan, 1991). In the former, the polymer molecule is successively hydrolysed completely before dissociation of the enzyme-substrate complex. While, in the latter, only one bond is hydrolysed per effective encounter. The multiple attack action is an intermediate between the single-chain and the multi-chain action (Bijttebier et al., 2008) where the enzyme cleaves several glycosidic bonds successively after the first (random) hydrolytic attack before dissociating from the substrate.

In short, it can clearly be seen that the multiple attack action is generally an accepted concept to explain the differences in action pattern of amylases (Kramhøft et al. 2005; Svensson et al. 2002). However, most of the endoamylases have a low to very low level of multiple attack action (Bijttebier et al., 2008). Although only few reports deal with the influence of $\mathrm{pH}$ and temperature on the action pattern of amylases, this influence was confirmed. Bijttebier et al. (2007) showed that the level of multiple attack of several endoamylases increased with temperature to a degree depending on the amylase itself.

\subsubsection{Molecular weight}

Despite wide difference of microbial $\alpha$-amylases characters, their molecular weights are usually in the same range 40-70 kDa (Gupta et al., 2003). Ratanakhanokchai et al. (1992) reported the highest molecular weight of $\alpha$-amylases, $210 \mathrm{kDa}$, for Chloroflexus aurantiacus. Whereas, $10 \mathrm{kDa}$ of Bacillus caldolyticus $\alpha$-amylase was reported to be the lowest value (Gupta et al., 2003).

This molecular weight may be raised due to glycosylation as in the case of T. vulgaris $\alpha$ amylase that reach $140 \mathrm{kDa}$ (Omar et al., 2011). In contrast, proteolysis may lead to decrease in the molecular weight. For example, $\alpha$-amylase of T. vulganis 94-2A (AmyTV1) is a protein of $53 \mathrm{kDa}$ and smaller peptides of 33 and $18 \mathrm{kDa}$ that have been shown to be products of limited AmyTV1 proteolysis (Hofemeister et al., 1994).

\subsubsection{Modular structure}

$\alpha$-amylases from different organisms share about $30 \%$ amino acid sequence identity and all belong to the same glycosyl hydrolase family 13 (Henrissat \& Bairoch, 1993). The three dimensional (3D) structures of $\alpha$-amylases have revealed monomeric, calcium-containing enzymes, with a single polypeptide chain folded into three domains (A-C).

The most conserved domain in $\alpha$-amylase family enzymes, the A-domain, consists of a highly symmetrical fold of eight parallel $\beta$-strands arranged in a barrel encircled by eight $\alpha$-helices. 
The highly conserved amino acid residues of the $\alpha$-amylase family involved in catalysis and substrate binding are located in loops at the C-termini of $\beta$-strands in this domain. This is typical to all enzymes belonging to the $\alpha / \beta$-barrel protein family (Farber \& Petsko, 1990).

$\alpha$-amylases have a B-domain that protrudes between $\beta$-sheet no 3 and $\alpha$-helix no. 3 . It ranges from 44 to 133 amino acid residues and plays a role in substrate or $\mathrm{Ca}^{2+}$ binding (Marc et al., 2002). The sequence of this domain varies most; in Bacillus $\alpha$-amylases it is relatively long and folds into a more complex structure of $\beta$-strands (Machius et al., 1995), whereas in barley $\alpha$-amylase there is an irregularly structured domain of 64 residues (Kadziola et al., 1994).

All known $\alpha$-amylases, with a few exceptions, contain a conserved $\mathrm{Ca}^{2+}$ binding site which is located at the interface between domains A and B (Linden et al., 2003; Prakash \& Jaiswal, 2010). In addition, $\alpha$-amylase produced by Bacillus thermooleovorans was found to contain a chloride ion binding site in their active site (Malhotra et al., 2000), which has been shown to enhance the catalytic efficiency of the enzyme, presumably by elevating the pKa of the hydrogen-donating residue in the active site (Prakash \& Jaiswal, 2010).

$\alpha$-amylases have a domain $C$ which is relatively conserved and folds into an antiparallel $\beta$ barrel. The orientation of domain $\mathrm{C}$ relative to domain $\mathrm{A}$ varies depending on the type and source of amylase (Bayer et al., 1995). The function of this domain is unknown.

Structural studies have confirmed that the active sites of glycosyl hydrolases are composed of multiple binding sites, or subsites, for the sugar units of polymeric substrates. The open active site cleft is formed between domains $\mathrm{A}$ and $\mathrm{B}$, so that residues from domain $\mathrm{B}$ participate in substrate binding. The substrate binding sites are commonly lined with aromatic residues which make hydrophobic stacking interactions with the sugar rings. In addition, the active sites contain many residues which form hydrogen bonds to the substrate either directly or via water molecules (Aleshin et al., 1994; Svensson \& Sogaard, 1993).

In Taka-amylase $\mathrm{A}$, the first examined protein $\alpha$-amylase by X-ray crystallography, three acidic residues, i.e., one glutamic and two aspartic acids were found at the centre of the active site (Matsuura et al., 1984), and subsequent mutational studies have shown that these residues are essential for catalysis (Janecek, 1997; Svensson, 1994). The glutamic acid residue is now believed to be the proton donor, while the first of the two conserved aspartic acids appearing in the amino acid sequence of an $\alpha$-amylase family member is thought to act as the nucleophile. The role of the second aspartic acid is less certain, but it has been suggested to be involved in stabilising the oxocarbenium ion-like transition state and also in maintaining the glutamic acid in the correct state of protonation for activity (Uitdehaag et al., 1999). These residues occur near the ends of strands 3, 4, 5 and 7 of the $\alpha / \beta$-barrel and are found in four short sequences, long-recognised as being conserved in $\alpha$-amylase family enzymes.

\subsubsection{Glycosylation}

Glycosylation is one of the major post-translation modifications that affect a variety of enzyme functions including secretion, stability, and folding (Barros et al., 2009; Shental- 
Bechor \& Levy, 2009). Oligosaccharides are usually linked to asparagine side chains (Nlinked glycosylation) or to serine and threonine hydroxyl side chains (O-linked glycosylation) (Shental-Bechor \& Levy, 2009).

Glycoproteins have been detected in $\alpha$-amylases of $A$. oryzae (Eriksen et al., 1998), B. stearothermophilus (Srivastava, 1984) and B. subtilis strains (Matsuzaki et al., 1974; Yamane et al., 1973). Generally, this is about $10 \%$ for most $\alpha$-amylases (Vihinen \& Mantsala, 1989). These carbohydrate moieties are thought to be responsible for high molecular weight of some $\alpha$-amylases. A carbohydrate content as high as $56 \%$ has been reported in S. castelii (Sills et al., 1984). Also, the high molecular weight $\alpha$-amylase of $140 \mathrm{kDa}$ produced by $T$. vulgaris (Abou Dobara et al., 2011) is a good example of highly glycosylated $\alpha$-amylase (Omar et al., 2011). Using SDS-PAGE, glycoproteins can be detected by initial oxidation of carbohydrates by periodic acid and subsequent staining with cationic dyes such as alcian blue (Wardi \& Michos, 1972).

\subsection{Production of microbial $\alpha$-amylases}

The major advantage of using microorganisms for the production of amylases is the economical bulk production capacity and easy manipulation of microbes to obtain enzymes of desired characteristics (Lonsane \& Ramesh, 1990). Screening for the $\alpha$-amylase producers is a key step for production. Starch hydrolysis is usually detected directly on plates as clear zones surrounding the colonies. The diameter of the area of hydrolysis, with in limits, was always related to the potency of the amylase (Dhawale et al., 1982).

\subsubsection{Factors affecting production}

The production and stability of $\alpha$-amylase in the medium is affected by a variety of physicochemical factors. In spite of expression's possibility under a wide range of culturing conditions, $\alpha$-amylase could be denatured under some conditions. Many proteins easily aggregate into so-called inclusion bodies during expression in bacterial systems (Espargaro et al., 2008). Inhibition of protein aggregation during fermentation/expression can be achieved by adjusting the production conditions (Bahrami et al., 2009; Hao et al., 2007).

Regarding to the incubation period, many investigators have found that extracellular $\alpha$ amylase production is growth associated (Abou Dobara et al., 2011; Asoodeh et al., 2010; Murthy et al., 2009). The changes in productivity of extracellular enzymes can be attributed to the differences in the timing of induction of separate components of the enzyme system, the inhibition by products of substrate hydrolysis and differential inactivation by proteases and/or variation in the $\mathrm{pH}$ during cultivation conditions (Tuohy \& Coughlan, 1992; J.P. Wang et al., 1993). The accumulation of sugars over a critical concentration in the medium is well documented to inhibit the enzyme production (Dona et al., 2010; J.P. Wang et al., 2006).

Among the physical parameters, the temperature and $\mathrm{pH}$ of the medium play an important role in $\alpha$-amylase production and stability. Generally, the influence of temperature on amylase production is related to the growth of the organism. Hence, the optimum 
temperature depends on whether the culture is mesophilic, thermophilic or psycrophilic. Among the fungi and actinomycetes, most amylase production studies achieved the optimum yields within the range $25^{\circ} \mathrm{C}-40^{\circ} \mathrm{C}$ (Gupta et al., 2003). However, thermophilic fungi ,such as Thermomyces lanuginosus (Mishra \& Maheshwari, 1996), and actinomycetes, namely; Thermomonospora fusca (Busch \& Stutzenberger, 1997) and Thermoactinomyces vulgaris (Abou Dobara et al., 2011) have been reported to produce $\alpha$-amylase optimally at 50 ${ }^{\circ} \mathrm{C}, 55^{\circ} \mathrm{C}$ and $55^{\circ} \mathrm{C}$, respectively. On the other hand, it has been produced at a wider range of optimal temperature by bacteria reaching to $90^{\circ} \mathrm{C}$ in Thermococcale and Sulfolobus species (Leuschner \& Antranikian, 1995; Sunna et al., 1997). Also, the $\mathrm{pH}$ values were reported to serve as an indicator of the initiation and end of enzyme synthesis (Friedrich et al., 1989) because the change in $\mathrm{pH}$ affects $\alpha$-amylase stability in the medium (Calamai et al., 2005). It is worth noting that the $\alpha$-amylase active site consists of a large number of charged groups (Lawson et al., 1994; Strokopytov et al., 1996; Uitdehaag et al., 1999) which explain the fact that most $\alpha$-amylases had optimum $\mathrm{pH}$ in the acidic to neutral range (Bozic et al., 2011; Pandey et al., 2000; Sun et al., 2010).

In general, amylase activity is connected with the substrate utilization. The inducibility nature of $\alpha$-amylase has been assured in different microorganisms (Abou Dobara et al., 2011; Aiyer, 2004; Asoodeh et al., 2010; Ryan et al., 2006). $\alpha$-amylase production is also appeared to be subjected to catabolite repression by maltose and glucose, like most other inducible enzymes that are affected by substrate hydrolytic products (Bhella \& Altosaar, 1988; Morkeberg et al., 1995). However, $\alpha$-amylase synthesis by Bacillus strains was reported to not subject to catabolite repression by monosaccharides (Kalishwaralal et al., 2010). Gupta et al. (2003) have classified xylose and fructose as strongly repressive to $\alpha$-amylase synthesis. Addition of starch to the medium has normally been employed for the production of $\alpha$ amylase from various microorganisms as reported in the literature.

Nitrogen source as a basal component of the medium is a major factor affecting $\alpha$-amylase production. Its effect was not only as a nitrogen source but also as a metal ion source and a $\mathrm{pH}$ controller as well. Many investigators had recorded that organic nitrogen sources supported maximum $\alpha$-amylase production by various bacteria (Abou Dobara et al., 2011; Aqeel \& Umar, 2010; Mrudula \& Kokila, 2010; Saxena et al., 2007). The increased $\alpha$-amylase production by organic nitrogen sources could be attributed to the high nutritional amino acids and vitamins content. However, various inorganic salts have been reported to support better production in fungi (Gupta et al., 2003). As a metal ion source, ammonium chloride was found to enhance the production of the $\alpha$-amylase by T. vulgaris, where chloride is a stabilizer, over that of other ammonium salts (Abou Dobara et al., 2011). In addition, the same authors also reported different productivity of $\alpha$-amylase by using sodium nitrate from potassium nitrate.

\subsubsection{Activity measurement of enzyme}

The diversity and heterogeneity of natural substrates coupled with the mixed specificities of individual enzymes presents a problem in the characterization of amylases. Furthermore, 
the enzymatic degradation of native insoluble substrates involves steps and mechanisms which are not yet understood at the molecular level. Therefore biochemical studies always use starch in some modified form to simplify analyses. There are basically four different types of substrates used for activity measurements: purified insoluble substrates approximated to a native substrate, modified insoluble substrates, soluble modified polysaccharides and soluble oligosaccharides. Catalytic activity is usually measured by quantifying formed soluble saccharides or chromophoric aglycon. The action of enzyme on insoluble substrates can also be assayed by other means. For example, a viscosimetric method has been used to measure $\alpha$-amylase activity on starch pastes (Marciniak \& Kula, 1982).

The measurement of soluble products from insoluble or soluble polymeric substrates often means assaying the formed reducing sugars. One of the simplest and most widely used is the 3, 5-dinitrosalisylic acid (DNS) method (Miller, 1959). However, the colour development in the reaction is not strictly proportional to the number of reducing sugars present, but also to the length of the oligosaccharides, leading to higher apparent reducing values with longer sugars (Robyt \& Whelan, 1972). DNS itself also breaks down the substrate. Several other reducing sugar determination methods have also been developed. In some cases dye groups have been attached to the polymeric substrate, e.g. dyed amylose-and amylopectin (Klein et al., 1970) and dyed and cross-linked starch (Cesk et al., 1969). The enzymatic assay is based on colour released from the substrate.

Starch forms a deep blue complex with iodine and with progressive hydrolysis of the starch, it changes to red brown. Several procedures have been described for the quantitative determination of amylase based on the reduction in blue colour intensity resulting from enzyme hydrolysis of starch (Swain et al., 2006). This method determines the dextrinising activity of $\alpha$-amylase in terms of decrease in the iodine colour reaction. Also, the coupled assay methods have been used for amylases, in which the concentration of released glucose is determined either by glucose oxidase/peroxidase (Kunst et al., 1984) or by hexokinase/glucose-6-phosphate dehydrogenase method (Rauscher, 1984).

Generally, various available methods for the determination of $\alpha$-amylase activity are based on decrease in starch-iodine colour intensity, increase in reducing sugars, degradation of colour-complexed substrate and decrease in viscosity of the starch suspension.

\subsubsection{Purification of enzyme}

Purification is a key step in the enzymes production where residual cell proteins and other contaminants are removed. Different techniques have been developed for purification of enzymes based on their properties, prior to their characterization or use in biotechnological and industrial processes. The commercial use of $\alpha$-amylase generally does not require purification of the enzyme but enzyme applications in food industries, pharmaceutical and clinical sectors require high purity amylases. The enzyme in purified form is also a prerequisite in studies of structure-function relationships and biochemical properties. 
The used methods to purify amylases can vary considerably, but most purification protocols involve a series of steps (Sun et al., 2010). The choice of purification protocol naturally depends on the intended use, the highest purity usually being required for basic purposes in which even separation of isozymes may be important. The purity and the yield attained depend on the number of steps and separation techniques employed.

The purification of $\alpha$-amylases from microbial sources in most cases has involved classical purification methods. These methods involve separation of the culture from the fermentation broth, selective concentration by precipitation using ammonium sulphate or organic solvents. The crude enzyme is then subjected to chromatography. The most commonly used techniques are usually affinity chromatography, ion exchange, and/or gel filtration. Cross-linked starch or starch derivatives are useful affinity adsorbents for the isolation of bacterial $\alpha$-amylases (Somers et al., 1995). Primarini \& Ohta (2000) isolated and separated two pure $\alpha$-amylases from Streptomyces sp. using starch adsorption, $\alpha-\mathrm{CD}$ Sepharose 6B and DEAE-Toyopearl 650M. Adsorption of $\alpha$-amylase, from Streptomyces sp. E-2248; on starch followed by separation on DEAE-Toyopearl and Toyopearl-HW55S gave the highest purification (2130-fold) (Kaneko et al., 2005). Also, $\alpha$-amylase from Bacillus licheniformis has been purified 6-fold with a yield of $38 \%$ using by two gel filtration chromatography steps on Sephadex G-100 and Superose 12 column (Bozic et al., 2011).

In addition to the classical chromatographic techniques, immunoaffinity chromatography has been applied for the preparation of highly purified amylases (Jang et al., 1994). Recent advances in the understanding of the physical and functional properties of amylases, and of the selectivity and capacity of the adsorbents, have led to greater rationality in the design of separation methods. However, the potential of the methods for the separation of amylases has not been fully exploited.

\subsubsection{Industrial desirable aspects}

The stability of biocatalysts is often a limiting factor in the selection of enzymes for industrial applications due to the elevated temperature or extreme $\mathrm{pH}$ of many biotechnological processes. Therefore, there is a continuing demand to improve the stability of the enzymes and thus meet the requirements set by specific applications.

As an example, the problem with traditional detergent enzymes is that they have to function in a washing machine under conditions that are very unfavorable for the stability of the enzyme. The $\mathrm{pH}$ is highly alkaline in washing conditions. The high temperature $\left(55-60^{\circ} \mathrm{C}\right)$ in a dishwasher requires thermostable enzymes. In addition, it is preferred to be resistant to various detergent ingredients, such as surfactants, chelating and oxidative agents (bleach).

In general, temperature has a complex effect on protein either directly or indirectly for both physical and chemical induced aggregation processes (Y.W. Wang et al., 2010). Therefore, it is the most critical environmental factor for consideration when proteins are handled during the entire development and commercialization processes. The advantages for using thermostable $\alpha$-amylases in industrial processes include the decreased risk of 
contamination, the increased diffusion rate and the decreased cost of external cooling. In short, almost all industries need thermostable enzymes. Besides thermostability and other factors such as activity with high concentrations of starch, i.e. more than $30 \%$ dry solids, or the protein yields of the industrial fermentation are important criteria for commercialization (Schäfer et al., 2000). Also, $\alpha$-amylases with wide $\mathrm{pH}$ range is desired to satisfy all applications either acidic as glucose syrup production or alkali as detergents industries.

However, there is a recent trend to use intermediate temperature stable (ITS) $\alpha$-amylases (Ahuja et al., 1998, as cited in Gupta et al., 2003). Olesen (1991) found that this feature render the enzyme to be useful for baking industry through avoiding stickiness in bread. Also, a modern trend among consumers is to use colder temperatures for doing the laundry or dishwashing. At these lower temperatures, detergents with $\alpha$-amylases optimally working at moderate temperatures and alkaline $\mathrm{pH}$ would be favourable (Marc et al., 2002). Although a wide variety of microbial $\alpha$-amylases is known, $\alpha$-amylase with 'ITS' property has been reported from only a few microorganisms (Gigras et al., 2002).

Another important desirable feature is calcium independency. Most known $\alpha$-amylases, with a few exceptions, contain a conserved $\mathrm{Ca}^{2+}$ binding site (Linden et al., 2003; Prakash \& Jaiswal, 2010) which make calcium be important to the enzyme activity. In manufacture of fructose syrup, the $\mathrm{Ca}^{2+}$ ions inhibit the glucose isomerase enzyme used in the final step of the process (Tonkova, 2006) and may lead to the formation of inorganic precipitates which have deleterious effects on fermentation and downstream processing (Kelly et al., 2009). Because the removal of these metal ions is both cost and time consuming to the overall industrial process (Kelly et al., 2009), the use of stable and functional $\alpha$-amylases in the absence of $\mathrm{Ca}^{2+}$ ions at high temperatures would be highly favored.

\section{Biodegradation of starch}

The degradation of starch occurs mainly through the action of microorganisms in plant litter and soil. Since the native substrate is water-insoluble and cannot penetrate into cells, the biodegradation of starch occurs extracellularly. Amylases are mainly secreted into the medium or are found membrane-bound. Some microbial strains are known to produce intracellular amylases; the reason for this is unknown (Vihinen \& Mantsala, 1989).

\subsection{Enzymatic degradation of starch}

The effective hydrolysis of starch demands the action of many enzymes due to its complexity, although a prolonged incubation with one particular enzyme can lead to (almost) complete hydrolysis. Few microorganisms produce a complete set of enzymes capable of degrading starch efficiently. There are basically four groups of starch-converting enzymes: (i) endoamylases; (ii) exoamylases; (iii) debranching enzymes; and (iv) transferases.

Endoamylases are able to cleave $\alpha, 1-4$ glycosidic bonds present in the inner part (endo-) of the amylose or amylopectin chain. Exoamylases act on the external glucose residues of 
amylose or amylopectin and thus produce only glucose (glucoamylase and $\alpha$-glucosidase), or maltose and $\beta$-limit dextrin ( $\beta$-amylase).

The third group of starch-converting enzymes is the debranching enzymes that exclusively hydrolyze $\alpha, 1-6$ glycosidic bonds: isoamylase (EC 3.2.1.68) and pullulanase type I (EC 3.2.1.41). These enzymes exclusively degrade amylopectin, thus leaving long linear polysaccharides. There are also a number of pullulanase type enzymes that hydrolyze both $\alpha, 1-4$ and $\alpha, 1-6$ glycosidic bonds. These belong to the group II pullulanase and are referred to as $\alpha$-amylase-pullulanase or amylopullulanase. The main degradation products are maltose and maltotriose.

The fourth group of starch-converting enzymes are transferases that cleave an $\alpha, 1-4$ glycosidic bond of the donor molecule and transfer part of the donor to a glycosidic acceptor with the formation of a new glycosidic bond. Enzymes such as amylomaltase (EC 2.4.1.25) and cyclodextrin glycosyltransferase (EC 2.4.1.19) form a new $\alpha, 1-4$ glycosidic bond while branching enzyme (EC 2.4.1.18) forms a new $\alpha, 1-6$ glycosidic bond. Cyclodextrin glycosyltransferases have a very low hydrolytic activity and make cyclic oligosaccharides with 6, 7, or 8 glucose residues and highly branched high molecular weight dextrins, the cyclodextrin glycosyltransferase limit dextrins. Amylomaltases are very similar to cyclodextrin glycosyltransferases with respect to the type of enzymatic reaction. The major difference is that amylomaltase performs a transglycosylation reaction resulting in a linear product while cyclodextrin glycosyltransferase gives a cyclic product.

Depending on the relative location of the bond under attack as counted from the end of the chain, the products of this digestive process are dextrin, maltotriose, maltose, and glucose, etc. Dextrins are shorter, broken starch segments that form as the result of the random hydrolysis of internal glucosidic bonds. A molecule of maltotriose is formed if the third bond from the end of a starch molecule is cleaved; a molecule of maltose is formed if the point of attack is the second bond; a molecule of glucose results if the bond being cleaved is the terminal one; and so on.

Most of the enzymes that convert starch belong to one family based on the amino acid sequence homology: the $\alpha$-amylase family or family 13 glycosyl hydrolases according to the classification of Henrissat (1991). Other little enzymes that convert starch don't belong to family 13 glycosyl hydrolases like $\beta$-amylases that belong to family 14 glycosyl hydrolases (Henrissat \& Bairoch, 1993); and glucoamylases which belong to family 15 glycosyl hydrolases (Aleshin et al., 1992).

\subsection{Catalytic mechanism and substrate binding}

The $\alpha$-glycosidic bond is very stable having a spontaneous rate of hydrolysis of approximately $2 \times 10^{-15} \mathrm{~s}^{-1}$ at room temperature (Wolfenden et al., 1998). Members of the $\alpha$ amylase family enhance this rate so enormously that they can be considered to belong to the most efficient enzymes known. 
The $\alpha$-amylase family enzymes always carry strictly conserved three essential catalytic residues (Matsuura et al., 1984). Of these three residues, the roles of Glu230 and Asp206 have been generally accepted as working for acid (proton donor) and base (nucleophile) catalyst, respectively (Janecek, 1997; Svensson, 1994). The catalytic mechanism has been discussed mostly on the basis of these two residues. However, the critical role of the third residue Asp297 seems to be still undefined and under dispute, except the facts that it plays an important role in the distortion of the substrate (Uitdehaag et al., 1999).

The generally accepted catalytic mechanism of the $\alpha$-amylase family is that of the $\alpha$ retaining double displacement (Koshland, 1953). The mechanism involves two catalytic residues in the active site; a glutamic acid as acid/base catalyst and an aspartate as the nucleophile. It involves five steps: (i) after the substrate has bound in the active site, the glutamic acid in the acid form donates a proton to the glycosidic bond oxygen, i.e. the oxygen between two glucose molecules at the subsites -1 and +1 and the nucleophilic aspartate attacks the $\mathrm{C} 1$ of glucose at subsite -1 ; (ii) an oxocarbonium ion-like transition state is formed followed by the formation of a covalent intermediate; (iii) the protonated glucose molecule at subsite +1 leaves the active site while a water molecule or a new glucose molecule moves into the active site and attacks the covalent bond between the glucose molecule at subsite -1 and the aspartate; (iv) an oxocarbonium ion-like transition state is formed again; (v) the base catalyst glutamate accepts a hydrogen from an incoming water or the newly entered glucose molecule at subsite +1 , the oxygen of the incoming water or the newly entered glucose molecule at subsite +1 replaces the oxocarbonium bond between the glucose molecule at subsite -1 and the aspartate forming a new hydroxyl group at the $\mathrm{C} 1$ position of the glucose at subsite -1 (hydrolysis) or a new glycosidic bond between the glucose at subsite -1 and +1 (transglycosylation). Studies with cyclodextrin glycosyltransferase have shown that the intermediate indeed has a covalently linked bond with the enzyme (Uitdehaag et al., 1999).

Other conserved amino acid residues e.g. histidine, arginine, and tyrosine play a role in positioning the substrate into the correct orientation into the active site, proper orientation of the nucleophile, transition state stabilization, and polarization of the electronic structure of the substrate (Lawson et al., 1994; Strokopytov et al., 1996; Uitdehaag et al., 1999).

\section{Biotechnological application}

Nowadays, $\alpha$-amylases represent one of the most important enzyme groups within the field of biotechnology. These enzymes are present in numerous biotechnological and industrial applications such as in food, detergents and textiles as well as in paper industry, for the hydrolysis of starch. They can also be of potential use in the pharmaceutical and fine chemical industries.

\subsection{Industrial production of glucose and fructose from starch}

The acid hydrolysis method for glucose production has been replaced recently by enzymatic treatment, with three or four different enzymes, in which $\alpha$-amylase is the first (Crabb \& Shetty, 1999). 
For the complete conversion into high glucose syrup, the first step is the liquefaction into soluble, short-chain dextrins. Dry solids starch slurry $(30-35 \%)$ of $\mathrm{pH} 6$ is mixed with $\alpha$ amylase and passed through a jet cooker after which the temperature is kept at $95-105{ }^{\circ} \mathrm{C}$ for $90 \mathrm{~min}$ to assure the removal of lipid-starch complexes. The dextrose equivalent value of starch hydrolysate syrup depends on the time of incubation and the amount of added enzyme. The drawback of the currently used $\alpha$-amylases is that they are not active at a $\mathrm{pH}$ below 5.9 at the high used temperatures. Therefore, the $\mathrm{pH}$ has to be adjusted from the natural $\mathrm{pH} 4.5$ of the starch slurry to $\mathrm{pH} 6$. Also $\mathrm{Ca}^{2+}$ needs to be added because of the $\mathrm{Ca}^{2+}-$ dependency of these enzymes (Tonkova, 2006). The next step is the saccharification of the starch hydrolysate syrup to high concentration glucose syrup, with more than $95 \%$ glucose. This is done by using an exo-acting glucoamylase. The final step is the conversion of high glucose syrup into high fructose syrup by using glucose isomerase (Bhosale et al., 1996).

\subsection{Bakery and anti-staling}

The baking industry is a large consumer of starch and starch-modifying enzymes. Amylases can be added to degrade the damaged starch in the flour into smaller dextrins, which are subsequently fermented by the yeast. Upon storage, all undesirable changes together are called staling. Retrogradation of the starch fraction in bread is considered very important in staling (Kulp \& Ponte, 1981). Staling is of considerable economic importance for the baking industry since it limits the shelf life of baked products. Several additives may be used in bread baking (Spendler \& Jórgensen, 1997) to delay staling and improve texture, volume and flavor of bakery products. Enzymes active on starch have been suggested to act as antistaling agents, especially $\alpha$-amylases (Sahlstrom \& Brathen, 1997).

$\alpha$-amylase supplementation in flour not only enhances the rate of fermentation and reduces the viscosity of dough resulting in improvements in the volume and texture of the product (De Stefanis \& Turner, 1981) but also it generates additional sugar in the dough, which improves the taste, crust colour and toasting qualities of the bread (Van Dam \& Hille, 1992). A recent trend is to use intermediate temperature stable (ITS) $\alpha$-amylases (Ahuja et al., 1998, as cited in Gupta et al., 2003) since they become inactive much before the completion of the baking process which avoid sickliness in bread.

\subsection{Cyclodextrin formation}

Cyclodextrins are cyclic $\alpha, 1-4$ linked oligosaccharides mainly consisting of 6,7 , or 8 glucose residues. The glucose residues in the rings are arranged in such a manner that the inside is hydrophobic while the outside is hydrophilic. This enables cyclodextrins to form inclusion complexes with a variety of hydrophobic guest molecules. The formation of inclusion complexes leads to changes in the chemical and physical properties of the guest molecules. These altered characteristics of the encapsulated compounds have led to various applications of cyclodextrins in analytical chemistry, agriculture, pharmacy, food and cosmetics. For the industrial production of cyclodextrins, starch is first liquefied by a heat- 
stable $\alpha$-amylase and then the cyclization occurs with a cyclodextrin glycosyltransferase (Riisgaard, 1990).

\subsection{Detergent industries}

A growing area of application of $\alpha$-amylases is in the fields of laundry, dish-washing detergents and spot removers (Borchet et al., 1995; Kennedy et al., 1988). Amylases have the function of facilitating the removal of starchy stains by means of catalytic hydrolysis of the starch polysaccharide, and have been used for this purpose for a fairly long time in dishwashing detergents and textile laundering (Speckmann et al., 2001).

Traditional detergent enzymes are functional under alkaline conditions, thermostable and resistant to various detergent ingredients, such as surfactants, chelating and oxidative agents. On the other hand, a modern trend among consumers is to use colder temperatures for doing the laundry or dishwashing. At these lower temperatures, the removal of starch from cloth and porcelain becomes more problematic. Detergents with $\alpha$-amylases optimally working at moderate temperatures and alkaline $\mathrm{pH}$ can help solve this problem (Marc et al., 2002).

\subsection{Ethanol production}

For large-scale processing, the bioconversion of starchy materials to ethanol is very useful because it can be used as a biofuel and as the starting material for various chemicals. The production of ethanol from starchy biomass commonly involves three-step processes: liquefaction of starch by an endoamylase such as $\alpha$-amylase to reduce the viscosity of the gelatinized starch produced after the cooking of the grains, enzymatic saccharification of the low-molecular-weight liquefaction products to produce glucose, and fermentation of glucose.

However, the present process for ethanol production from starchy materials via fermentation requires improvement of cost production. Although noncooking and lowtemperature-cooking fermentation systems (Matsumoto et al., 1982) have succeeded in reducing energy consumption by approximately 50\% (Matsumoto et al., 1982), it is still necessary to add large amounts of amylolytic enzymes to hydrolyze the starchy materials. Many researchers have reported attempts to resolve this problem by using recombinant glucoamylase-expressing yeasts with the ability to ferment starch to ethanol directly (Kondo et al., 2002). Also, a noncooking fermentation system using a cell surface-engineered yeast strain promises to be very effective in reducing the production costs of ethanol (Shigechi et al., 2004). On the other hand, fermentation of starch to ethanol in one step using co-cultures of two different strains has been suggested and has potential application for the direct bioconversion of starch into ethanol (Zeikus, 1979).

\subsection{Miscellaneous applications}

Besides amylases' use in the saccharification or liquefaction of starch, these are also used for the clarification of formed haze in fruit juices, the pretreatment of animal feed to improve 
the digestibility (Marc et al., 2002). $\alpha$-amylase is used for the production of low viscosity, high molecular weight starch for coating of paper (Bruinenberg et al., 2004). Starch is a good sizing agent for the finishing of paper. It is added to the paper in the size press and paper picks up the starch by passing through two rollers that transfer the starch slurry. The temperature of this process lies in the range of $45-60{ }^{\circ} \mathrm{C}$. A constant viscosity of the starch is required for reproducible results at this stage. The mill also has the flexibility of varying the starch viscosity for different paper grades. The viscosity of the natural starch is too high for paper sizing and is adjusted by partially degrading the polymer with $\alpha$-amylases in a batch or continuous processes. Also, good desizing of starch sized textiles is achieved by the application of $\alpha$-amylases, which selectively remove the size and do not attack the fibers. It also randomly cleaves the starch into dextrins that are water soluble and can be removed by washing.

Furthermore, high molecular weights amylases were found in culture supernatants of an environmentally derived microbial mixed culture selected for its ability to utilize starchcontaining plastic films as sole carbon sources (Burgess-Cassler et al., 1991). This suggests a new application for amylases in biodegradation. With the advent of new frontiers in biotechnology, the spectrum of amylase applications has expanded into many other fields, such as clinical, medicinal and analytical chemistry (Becks et al., 1995).

A modern trend is to use starch for production of a more efficient and specific degradation products through a particular combination of activities. Amylase from Aspergillus niger, a saccharifying enzyme which produces maltose, maltotriose and some glucose, is capable of alcoholysis for the synthesis of methyl-glucosides from starch in the presence of methanol. As these products are a series of methyloligosaccharides, from methyl-glucoside to methylhexomaltoside, the biotechnological applications of using starch as substrate for the production of alkyl-glucosides is analyzed (Santamaria et al., 1999).

Moreover, it becomes possible to produce lactic acid directly from starch by an efficient simultaneous saccharification and fermentation from soluble starch by recombinant Lactobacillus strains (Okano et al., 2009). Finally, $\alpha$-amylase is suggested as an enzyme that contributes to the reduction of $\mathrm{AuCl}_{4}^{-}$to gold nanoparticles (Au-NPs) which makes it ideal for the production of Au-NPs (Kalishwaralal et al., 2010).

\section{Conclusion}

Despite the fact that several different $\alpha$-amylase preparations are available with various enzyme manufacturers for specific use in varied industries, amylase biotechnology demands extension in terms of both quality and quantity. Qualitative improvements in amylase gene and its protein can be achieved by recombinant DNA technology and protein engineering. Quantitative enhancement needs strain improvement through site directed mutagenesis and/or standardizing the nutrient medium for the overproduction of active $\alpha$-amylases. Another approach is to screen for novel microbial strains from extreme environments. 
All the above-mentioned approaches are aimed to increase stability, improve product specificity, alter $\mathrm{pH}$ optimum, improve thermostability, achieve free $\mathrm{Ca}^{+2}$ requirement; by using the currently available insights into the structure-function relationships of the amylase family enzymes.

\section{Author details}

Amira El-Fallal, Mohammed Abou Dobara, Ahmed El-Sayed and Noha Omar Faculty of Science, Damietta Branch, Egypt

\section{Acknowledgement}

The authors are greatly acknowledging Damietta Branch, Mansoura University for supporting this work.

\section{References}

Abou Dobara, M.I., El-Sayed, A.K., El-Fallal, A.A \& Omar, N.F. (2011). Production and partial characterization of high molecular weight extracellular $\alpha$-amylase from Thermoactinomyces vulgaris isolated from Egyptian soil. Polish Journal of Microbiology, Vol. 60, No. 1, (January 2011), pp. 65- 71, ISSN 1733-1331

Aiyer, P. (2004). Effect of C: $\mathrm{N}$ ratio on alpha amylase production by Bacillus licheniformis SPT 27. African Journal of Biotechnology, Vol. 3, No. 10, (October 2004), pp. 519-522, ISSN 1684-5315

Aleshin, A., Firsov, L. \& Honzatko, R. (1994). Refined structure for the complex of acarbose with glucoamylase from Aspergillus awamori Var. X100 to 2.4-A resolution. J. Biol. Chem., Vol. 269, No. 22, (June 1994), pp. 15631-15639, ISSN 1083-351X

Aleshin, A., Firsov, L. \& Honzatko, R. (1994). Refined structure for the complex of acarbose with glucoamylase from Aspergillus awamori Var. X100 to 2.4-A resolution. J. Biol. Chem., Vol. 269, No. 22, (June 1994), pp. 15631-15639, ISSN 1083-351X

Andrews, L. \& Ward, J. (1987). Extracellular amylases from Streptomyces albus. J. Biochem. Soc. Trans., Vol. 15, No.3, (June 1987), pp. 522-523, ISSN 1470-8752

Aqeel, B. \& Umar, D. (2010). Effect of alternative carbon and nitrogen sources on production of alpha-amylase by Bacillus megaterium. World Applied Sciences Journal, Vol. 8, Special Issue of Biotechnology \& Genetic Engineering, pp. 85-90, ISSN 0264-8725

Arnesen, S., Eriksen, S.H., Olsen, J. \& Jensen, B. (1998). Increased production of alpha amylase from Thermomyces lanuginosus by the addition of Tween-80. Enzyme Microb. Technol., Vol. 23, No. 3-4, (November 1998), pp. 249-252, ISSN 0141-0229

Asoodeh, A., Chamanic, J. \& Lagzian, M. (2010). A novel thermostable, acidophilic $\alpha-$ amylase from a new thermophilic "Bacillus sp. Ferdowsicous" isolated from Ferdows hot mineral spring in Iran: Purification and biochemical characterization. Int. J. Biol. Macromol., Vol. 46, No. 3, (April 2010), pp. 289-297, ISSN 0141-8130 
Aunstrup, K. (1979). Production, isolation and economics of extracellular enzymes, In: Applied Biochemistry and Bioengineering, J. Wingard, L. Katchalski - Katzir \& L. Golstein (Ed.), pp. (27-69), Academic Press, ISBN 0120411024, New York, USA

Azhari, R. \& Lotan, N. (1991). Enzymic hydrolysis of biopolymers via single-scission attack pathways: a unified kinetic model. J. Mater. Sci. Mater. Med., Vol. 2, No. 1, (January 1991), pp. 9-18, ISSN 1573-4838

Bahrami, A., Shojaosadati, S., Khalilzadeh, R., Mohammadian, J., Farahani, E. \& Masoumian, M. (2009). Prevention of human granulocyte colony-stimulating factor protein aggregation in recombinant Pichia pastoris fed-batch fermentation using additives. Biotechnol. Appl. Biochem., Vol. 52, No. 2, (February 2009), pp. 141-148, ISSN 1470-8744

Bahri, S. \& Ward, J. (1990). Cloning and expression of an $\alpha$-amylase gene from Streptomyces thermoviolaceus CUB74 in Escherichia coli JM107 and S. lividans TK24. J. Gen. Microbiol., Vol. 136, No. 5, (May 1990), pp. 811-818, ISSN 1465-2080

Bajpai, P. \& Bajpai, P.K. (1989). High-temperature alkaline $\alpha$-amylase from Bacillus licheniformis TCRDC-B13. Biotechnol. Bioeng., Vol. 33, No. 1, (January 1989), pp. 72-78, ISSN 1097-0290

Barros, M., Silva, R., Ramada, M., Galdino, A., Moraes, L., Torres, F. \& Ulhoa, C. (2009). The influence of $\mathrm{N}$-glycosylation on biochemical properties of Amy1, an $\alpha$-amylase from the yeast Cryptococcus flavus. Carbohydrate Research, Vol. 344, No. 13, (September 2009), pp. 1682-1686, ISSN 0008-6215

Bayer, E., Morag, E., Wilcheck, M., Lamed, R., Yaron, S. \& Shoham, Y. (1995). Cellulosome domains for novel biotechnological application. In: Carbohydrate bioengineering, B. Petersen, B. Srensson \& S. Pedersen (Ed.), pp. (251-259), Progress in biotechnology, Elsevier, ISBN 0-444-82223-2, The Netherlands.

Becks, S., Bielawaski, C., Henton, D., Padala, R., Burrows, K. \& Slaby, R. (1995). Application of a liquid stable amylase reagent on the ciba corning express clinical chemistry system. Clin. Chem., Vol. 41, No. 2, (February 1995), pp. 186, ISSN 1530-8561

Bertoft, E. (2007). Composition of clusters and their arrangement in potato amylopectin. Carbohydrate Polymers, Vol. 68, No. 3, (April 2007), pp. 433-446, ISSN 0144-8617

Bhella, R.S. \& Altosaar, I. (1988). Role of CAMP in the mediation of glucose catabolite repression of glucoamylase synthesis in Aspergillus awamori. Curr. Genet, Vol. 14, No. 3, (September 2004), pp. 247-252, ISSN 1432-0983

Bhosale, S., Rao, M. \& Deshpande, V. (1996). Molecular and industrial aspects of glucose isomerase. Microbiol. Rev., Vol. 60, No. 2, (June 1996), pp. 280-300, ISSN 1098-5557

Bijttebier A., Goesaert H. \& Delcour J.A. (2007). Temperature impacts the multiple attack action of amylases. Biomacromolecules, Vol. 8, No. 3, (March 2007), pp. 765-772, ISSN 1526-4602

Bijttebier, A., Goesaert, H. \& Delcour, J. (2008). Amylase action pattern on starch polymers. Biologia, Vol. 63, No. 6, (December 2008), pp. 989-999, ISSN 1336-9563

Borchet, T., Lassen, S., Svendsen, A. \& Frantzen, H. (1995). Oxidation stable amylases for detergents. In: Carbohydrate bioengineering: Progress in biotechnology. Vol. 10, S. Petersen, 
B. Svensson \& S. Pedersen (Ed.), pp. (175-179), Elsevier, ISBN 0444822232, The Netherlands.

Bozic, N., Ruizb, J., López-Santínb, J. \& Vujci'c, Z. (2011). Production and properties of the highly efficient raw starch digesting $\alpha$-amylase from a Bacillus licheniformis ATCC 9945a. Biochemical Engineering Journal, Vol. 53, No. 2, (January 2011), pp. 203-209, ISSN 1369-703X

Brooker, J.D. \& McCarthy, J.M. (1997). Gene knockout of the intracellular amylase gene by homologous recombination in Streptococcus bovis. Curr. Microbiol., Vol. 35, No. 3, (September 1997), pp. 133-138, ISSN 1432-0991

Bruinenberg, P.M., Hulst, A.C., Faber, A. \& Voogd, RH. (2004). A process for surface sizing or coating of paper, In: European Patent Application no. EP0690170, April 2012, Available from :< http://www.freepatentsonline.com/EP0690170.html>

Burgess-Cassler, A., Imam, S. \& Gould, J. (1991). High-Molecular-Weight Amylase Activities from Bacteria Degrading Starch-Plastic Films. Appl. Environ. Microbiol., Vol. 57, No. 2, (February 1991), pp. 612-614, ISSN 098-5336

Busch, J.E. \& Stutzenberger, F.J. (1997). Amylolytic activity of Thermomonospora fusca. World J. Microbiol. Biotechnol. Vol. 13, No. 6, (November 1997), pp. 637-642, ISSN 1573-0972

Calamai, M., Canale, C., Relini, A., Stefani, M., Chiti, F. \& Dobson, C.M. (2005). Reversal of protein aggregation provides evidence for multiple aggregated states. J. Mol. Biol. Vol. 346, No. 2, (February 2005), pp. 603-616, ISSN 0022-2836

Cesk, M., Brown, B. \& Birath, K. (1969). Ranges of $\alpha$-amylase activities in human serum and urine and correlations with some other $\alpha$-amylase methods. Clin. Chem. Acta., Vol. 26, No. 3, (December 1969), pp. 445-453, ISSN 0009-8981

Collins, B., Kelly, C., Fogarty, W. \& Doyle, E. (1993). The high maltose-producing alphaamylase of the thermophilic actinomycete Thermomonospora curvata. Appl. Microbiol. Biotechnol., Vol. 39, No.1 , (April 1993), pp. 31-35, ISSN 1432-0614

Coutinho, P. \& Henrissat, B. (1999). Carbohydrate active enzymes. In: Recent Advances in Carbohydrate bioengineering, H. Gilbert, G. Davies, B. Svensson \& B. Henrissat (Ed.), pp. (3-12), Royal Society of Chemistry, ISBN 0854047743, Cambridge

Crabb, W. \& Shetty, J. (1999). Commodity scale production of sugars from starches. Curr. Opin. Microbiol., Vol. 2, No. 3, (June 1999), pp. 252- 256, ISSN 1369-5274

De Mot, R., Andries, K. \& Verachtert, H. (1984a). Comparative study of starch degradation and amylase production by ascomycetous yeast species. Syst. Appl. Microbiol. Vol. 5, No. 1, (April 1984), pp. 106-118, ISSN 0723-2020

De Mot, R., Demeersman, M. \& Verachtert. H. (1984b). Comparative study of starch degradation and amylase production by non-ascomycetous yeast species. Syst. Appl. Microbiol. Vol. 5, No. 3, (October 1984), pp. 421-432, ISSN 0723-2020

De Mot, R., Van Oudendijck, E., Hougaerts, S. \& Verachtert. H. (1984c). Effect of medium composition on amylase production by some starch-degrading yeasts. FEMS Microbiol. Lett., Vol. 25, No. 2, (December 1984), pp. 169-173, ISSN 1574-6968

De Stefanis, V. \& Turner, E. (1981). Modified enzyme system to inhibit bread firming method for preparing same and use of same in bread and other bakery products, In: 
United states Patent Application no. US4299848, April 2012, Available from: $<$ http://patft.uspto.gov/netacgi/nphParser?Sect2=PTO1\&Sect2=HITOFF\&p=1\&u=/netaht $\mathrm{ml} / \mathrm{PTO} /$ searchbool.html\&r=1\&f=G\&l=50\&d=PALL\&RefSrch=yes\&Query=PN/4299848 >

Dhawale, M., Wilson, J., Khachatourians, G. \& Mike, W. (1982). Improved method for detection of starch hydrolysis. Appl. Eenviron. Microbiol., Vol. 43, No. 4, (April 1982), pp. 747-750, ISSN 1098-5336

Domsch, K.H., Gams, W. \& Anderson, T.H. (1995). Compendium of soil fungi, p. 859, IHWVerlag, ISBN 3980308383, Alemanha

Dona, A., Pages, G., Gilbert, R. \& Kuchel, P. (2010). Digestion of starch: In vivo and in vitro kinetic models used to characterise oligosaccharide or glucose release. Carbohydrate Polymers., Vol. 80, No. 3, (May 2010), pp. 599-617, ISSN 0144-8617

Doyle, E.M., Noone, A.M., Kelly, C.T., Quigley, T.A. \& Fogarty, W.M. (1998). Mechanisms of action of the maltogenic $\alpha$-amylase of Byssochlamys fulva. Enzyme Microb. Technol. Vol. 22, No. 7, (May 1998), pp. 612-616, ISSN 0141-0229

EL-Banna, T.E., Abd-Aziz, A.A., Abou-Dobara, M.I. \& Ibrahim, R.I. (2007). Production and immobilization of $\alpha$-amylase from Bacillus subtilis. Pakistan J. of Biological Sciences, Vol. 10, No. 12, (June 2007), pp. 2039-2047, ISSN 1812-5735

EL-Banna, T.E., Abd-Aziz, A.A., Abou-Dobara, M.I. \& Ibrahim, R.I. (2008). Optimization and immobilization of $\alpha$-amylase from Bacillus licheniformis, Proceedings of the second international conference on the role of genetics and biotechnology in conservation of natural resources, Ismailia, Egypt, July 2007.

Eriksen, S., Jensen, B. \& Olsen, J. (1998). Effect of N-linked glycosylation on secretion, activity and stability of $\alpha$-amylase from Aspergillus oryzae. Curr. Microbiol., Vol. 37, No. 2, (August 1998), pp. 117-122, ISSN 1432-0991

Espargaro, A., Castillo, V., de Groot, N. \& Ventura, S. (2008). The in vivo and in vitro aggregation properties of globular proteins correlate with their conformational stability: the SH3 case. J. Mol. Biol., Vol. 378, No. 5, (May 2008), pp. 1116-1131, ISSN 0022-2836

Farber, G. \& Petsko, G. (1990). The evolution of $\alpha / \beta$-barrel enzymes. TIBS, Vol. 15, No. 6, (June 1990), pp. 228-234, ISSN 0968-0004

French, D. (1984). Organization of starch granules, In: starch: chemistry and technology, R.L. Whistler, J.N. Bemiller \& E.F. Paschall (Ed.), pp. (183-207), Academic press, ISBN 78-012-746275-2, London.

Friedrich, J., Cimerman, A. \& Steiner, W. (1989). Submerged production of pectinolytic enzymes by Aspergillus niger: effect of different aeration/agitation regimes. Appl. Microbiol. Biotechnol. , Vol. 31, No. 5-6, (Octobar 1989), pp. 490-494, ISSN 1432-0614

Fukumoto, J. \& Okada, S. (1963). Studies on bacterial amylase, Amylase types of Bacillus subtilis species. J. Ferment. Technol., Vol. 41, No. 1, pp. 427-434, ISSN 0385-6380

Gerard, C., Planchot, V., Colonna, P. \& Bertoft, E. (2000). Relationship between branching density and crystalline structure of A- and B-type maize mutant starches. Carbohydr. Res. Vol. 326, No. 2, (June 2000), pp. 130-144, ISSN 0008-6215 
Gigras, P., Sahai, V. \& Gupta, R. (2002). Statistical media optimization and production of its alpha amylase from Aspergillus oryzae in a bioreactor. Curr. Microbiol., Vol. 45, No. 3, (September 2002), pp. 203-208, ISSN 1432-0991

Giraud, E., Brauman, A., Keleke, S., Lelong, B. \& Raimbault, M. (1991). Isolation and physiological study of an amylolytic strain of Lactobacillus plantarum. Appl. Microbiol. Biotechnol., Vol. 36, No. 3, (December 1991), pp. 379-383, ISSN 1432-0614

Gupta R., Paresh, G., Mohapatra, H., Goswami, V., \& Chauhan, B. (2003) Microbial $\alpha$ amylases: a biotechnological perspective. Process Biochem., Vol. 38, No. 12, (July 2003), pp. 1599-1616, ISSN 1359-5113

Hanashiro, I., Abe, J. \& Hizukuri, S. (1996). A periodic distribution of the chain length of amylopectin as revealed by high-performance anion-exchange chromatography. Carbohydr. Res. Vol. 283, No. 1, (March 1996), pp. 151-159, ISSN 0008-6215

Hang, M., Furuyoshi, S., Yagi, T. \& Yamamoto, S. (1996). Purification and characterization of raw starch digesting $\alpha$-amylase from Streptomyces thermocyaneoviolaceus IFO14271. J. Appl. Glycosci., Vol. 43, pp. 487-497, ISSN 1880-7291

Hao, Y., Chu, J., Wang, Y., Zhuang, Y. \& Zhang, S. (2007). The inhibition of aggregation of recombinant human consensus interferon-alpha mutant during Pichia pastoris fermentation. Appl. Microbiol. and Biotechnol., Vol. 74, No. 3, (March 2007), pp. 578-584, ISSN 1432-0614

Hayashi, T., Akiba, T. \& Horikoshi, K. (1988). Production and purification of new maltohexaose-forming amylases from alkalophilic Bacillus sp. H-167. Agric. Biol. Chem., Vol. 52, No. 2, (February 1988). pp. 443-448, ISSN 1881-1280

Henrissat, B. \& Bairoch, A. (1993). New families in the classification of glycosyl hydrolases based on amino acid sequence similarities. Biochem. J., Vol. 293, No. 3, (August 1993), pp. 781-788, ISSN 0264-6021

Henrissat, B. (1991). A classification of glycosyl hydrolases based on amino acid sequence similarities. Biochem.J., Vol. 280, No. 2, (December 1991), pp. 309-316, ISSN 0264-6021

Hofemeister, B., Konig, S., Hoang, V., Engel, J., Mayer, G., Hansen, G. \& Hofemeister, J. (1994). The gene amyE (TV1) codes for a nonglucogenic $\alpha$-amylase from Thermoactinomyces vulgaris 94-2A in Bacillus subtilis. Appl. Environ. Microbiol., Vol. 60, No. 9, (September 1994), pp. 3381-3389, ISSN 1098-5336

Hyun, H.H. \& Zeikus, J.G. (1985a). General biochemical characterization of thermostable extracellular $\beta$-amylase from Clostridium thermosulfurogenes. Appl. Environ. Microbiol., Vol. 49, No. 5, (May 1985), pp. 1162-1167, ISSN 1098-5336

Imberty, A., Buleon, A., Tran, V. \& Perez, S. (1991). Recent advances in knowledge of starch structure. Starch/Starke, Vol. 43, No. 10, (October 1991), pp. 375-384, ISSN 1521-379X

Janecek, S. (1997). $\alpha$-Amylase family: molecular biology and evolution. Prog. Biophys. Mol. Biol. Vol. 67, No. 1, (January 1997), pp. 67-97, ISSN 0079-6107

Jang, S., Cheong, T., Shim, W., Wan Kim, J. \& Park, K. (1994). Purification of Bacillus licheniformis thermostable $\alpha$-amylase by immunoaffinity chromatography. Korean Biochem. J., Vol. 27, No. 1, (January 1994), pp. 38-41, ISSN 0368-4881 
Kadziola, A., Abe, J., Svensson, B. \& Haser, R. (1994). Crystal and molecular structure of barley $\alpha$-amylase. J.Mol.Biol., Vol. 239, No. 1, (may 1994), pp. 104-121, ISSN 0022-2836

Kalishwaralal, K., Gopalram, S., Vaidyanathan, R., Deepak, V., Pandian, S. \& Gurunathan, S. (2010). Optimization of $\alpha$-amylase production for the green synthesis of gold nanoparticles. Colloids and Surfaces B: Biointerfaces, Vol. 77, No. 2, (June 2010), pp. 174180, ISSN 0927-7765

Kaneko, T., Ohno, T. \& Ohisa, N. (2005). Purification and characterization of a thermostable raw starch digesting amylase from a Streptomyces sp. isolated in a milling factory. Biosci. Biotechnol. Biochem., Vol. 69, No. 6, (June 2005), pp. 1073-1081, ISSN 1347-6947

Kelly, R., Dijkhuizen, L. \& Leemhuis, H. (2009). Starch and glucan acting enzymes, modulating their properties by directed evolution. Biotechnology, Vol. 140, No. 3-4, (March 2009), pp. 184-193, ISSN 0168-1656

Kennedy, J., Cabalda, V. \& White, C. (1988). Enzymic starch utilization and genetic engineering. Tibtech., Vol. 6, pp. 184-189, ISSN 0167-7799

Kim, T.U., Gu, B.G., Jeong, J.Y., Byun, S.M. \& Shin, Y.C. (1995). Purification and characterization of maltotetraose-forming alkaline $\alpha$-amylase from an alkalophilic Bacillus strain, GM8901. Appl. Environ. Microbiol., Vol. 61, No. 8, (August 1995), pp. 3105-3112, ISSN 1098-5336

Kimura, K., Tsukamoto, A., Ishii, Y., Takano, T. \& Yamane, K. (1988). Cloning of a gene for maltohexaose producing amylase of an alkalophilic Bacillus and hyper-production of the enzyme in Bacillus subtilis cells. Appl. Microbiol. Biotechnol. Vol. 27, No. 4, (January 1988), pp. 372-377, ISSN 1432-0614

Klein, B., Foreman, J. \& Searcy, R. (1970). New chromogenic substrate for determination of serum amylase activity. Clin. Chem., Vol. 16, No. 1, (January 1970), pp. 32-38, ISSN 15308561

Kondo, A., Shigechi, H., Abe, M., Uyama, K., Matsumoto, T., Takahashi, S., Ueda, M., Tanaka, A., Kishimoto, M. \& Fukuda, H. (2002). High-level ethanol production from starch by a flocculent Saccharomyces cerevisiae strain displaying cell-surface glucoamylase. Appl. Microbiol. Biotechnol., Vol. 58, No. 3, (March 2002), pp. 291-296, ISSN 1432-0614

Koshland, D.E. (1953). Stereochemistry and the mechanism of enzymatic reactions. Biol. Rev., Vol. 28, No. 4, (November 1953), pp. 416-436, ISSN 1469-185X

Kramhøft B., Bak-Jensen K., Mori H., Juge N., Nohr J. \& Svensson B. (2005). Involvement of individual subsites and secondary substrate binding sites in multiple attack on amylase by barley $\alpha$-amylase. Biochemistry, Vol. 44, No. 6, (February 2005), pp. 1824-1832, ISSN 1520-4995

Kulp, K. \& Ponte, J.G. (1981). Staling white pan bread: fundamental causes. Crit. Rev. Food Sci. Nutr., Vol. 15, No. 1, (January 1981), pp. 1-48, ISSN 1549-7852

Kunst A., Drager, B. \& Ziegenhorn, J. (1984). Colorimetric methods with glucose oxidase and peroxidase. In: Methods of enzymatic analysis, H. Bermeyer (Ed.), pp. (178-185), Weiheim, ISBN 3527255982, Verleg Chemie 
Kuo, M. \& Hartman, P. (1966). Isolation of amylolytic strains of Thermoactinomyces vulgaris and production of thermophilic actinomycete amylases. J. Bacteriol., Vol. 92, No. 3, (September 1966), pp. 723-726, ISSN 1098-5530

Lawson, C.L., van Montfort, R., Strokopytov, B., Rozeboom, H.J., Kalk, K.H., de Vries, G.E., Penninga, D., Dijkhuizen, L. \& Dijkstra, B.W. (1994). Nucleotide sequence and X-ray structure of cyclodextrin glycosyltransferase from Bacillus circulans strain 251 in a maltose-dependent crystal form. J. Mol. Biol. Vol. 236, No. 2, (February 1994), pp. 590600, ISSN 0022-2836

Leuschner, C. \& Antranikian, G. (1995). Heat-stable enzymes from extremely thermophilic and hyperthermophilic microorganisms. World J Microb Biot., Vol. 11, No. 1, (January 1995), pp. 95-114, ISSN 1573-0972

Liebl, W., Stemplinger, I. \& Ruile, P. (1997). Properties and gene structure of the Thermotoga maritima alpha-amylase AmyA, a putative lipoprotein of a hyperthermophilic bacterium. J. Bacteriol. Vol. 179, No.3, (February 1997), pp. 941-948, ISSN 1098-5530

Lim, W., Park, S., An, C., Lee, J., Hong, S., Shin, E., Kim, E., Kim, J., Kim, H.\& Yun, H. (2003). Cloning and characterization of a thermostable intracellular alpha-amylase gene from the hyperthermophilic bacterium Thermotoga maritima MSB8. Res. Microbiol. Vol. 154, No.10, (December 2003), pp. 681-687, ISSN 0923-2508

Linden, A., Mayans, O., Meyer-Claucke, W., Antranikian, G. \& Wilmanns, M. (2003). Differential regulation of a hyperthermophilic $\alpha$-amylase with a novel ( $\mathrm{Ca}, \mathrm{Zn})$ twometal center by zinc. J. Biological Chemistry, Vol. 278, No. 11, (March 2003), pp. 98759884, ISSN 1083-351X

Lonsane, B. \& Ramesh M. (1990). Production of bacterial thermostable [alpha]-Amylase by solid-state fermentation: a potential tool for achieving economy in enzyme production and starch hydrolysis. In: Advances in Applied Microbiol., Vol. 35, S. Neidleman \& A. Laskin (Ed.), pp. (1-56), Elsevier, ISBN 978-0-12-002635-7, The Netherlands.

Machius, M., Wiegand, G. \& Huber, R. (1995). Crystal structure of calcium depleted Bacillus licheniformis $\alpha$-amylase at 2.2 Å resolution. J.Mol.Biol., Vol. 246, No. 4, (March 1995), pp. 545-559, ISSN 0022-2836

Malhotra, R., Noorvez, S. \& Satyanarayana, T. (2000). Production and partial characterization of thermostable and calcium-independent $\alpha$-amylase of an extreme thermophile Bacillus thermooleovorans NP54. Letters in Applied Microbiology, Vol. 31, No. 5, (November 2000), pp. 378-384, ISSN 1472-765X

Marc, J.E., van der Maarel, C., Joost, B.V., Uitdehaag, C.M., Leemhuis, H. \& Dijkhuizen, L. (2002). Properties and applications of starch-converting enzymes of the $\alpha$-amylase family. J. Biotechnology, Vol. 94, No. 2, (March 2002), pp. 137-155, ISSN 0168-1656

Marciniak, G. \& Kula, M. (1982). Vergleichende untersuchung der methoden zur bestimmung der aktivität bakterieller alpha amylasen. Starch/starke, Vol. 34, No. 12, (December 1982), pp. 422-430, ISSN 1521-379X

Matsumoto, N., Fukushi, O., Miyanaga, M., Kakihara, K., Nakajima, E. \& Yoshizumi, H. (1982). Industrialization of a noncooking system for alcoholic fermentation from grains. Agric. Biol. Chem., Vol. 46, No. 6, (June 1982), pp. 1549-1558, ISSN 1881-1280 
Matsuura, Y., Kusunoki, M., Harada, W. \& Kakudo, M. (1984). Structure and possible catalytic residues of Taka amylase A. J. Biochem., Vol. 95, No. 3, (March 1984), pp. 697702, ISSN 1756-2651

Matsuzaki, H., Yamane, K., Yamaguchi, K., Nagata, Y. \& Maruo, B. (1974). Hybrid $\alpha-$ amylase produced by transformants of Bacillus subtilis I. Immunological and chemical properties of $\alpha$-amylases produced by the parental strain and the transformants. Biochim Biophys Acta., Vol. 367, No. 2, (October 1974), pp. 235-247, ISSN 0005-2736

McCann, A.K. \& Barnett. J.A. (1984). Starch utilization by yeasts: mutants resistant of carbon catabolite repression. Curr. Genet. Vol. 8, No. 7, (September 1984), pp. 525-530, ISSN 1432-0983

Miller, G.L. (1959). Use of dinitrosalisylic acid reagent for determination of reducing sugar. Anal. Chem., Vol. 31, No. 3, (March 1959), pp. 426-428, ISSN 1520-6882

Mishra, R.S. \& Maheshwari, R. (1996). Amylases of the thermophilic fungus Thermomyces lanuginosus: their purification, properties, action on starch and response to heat. J Biosci., Vol. 21, No. 5, (September 1996), pp. 653-672, ISSN 0973-7138

Morkeberg, R., Carlsen, M. \& Nielsen, J. (1995). Induction and repression of $\alpha$-amylase production in batch and continuous cultures of Aspergillus oryzae. Microbiol., Vol. 141, No. 10, ( October 1995), pp. 2449-2454, ISSN 1465-2080

Murthy, P., Naidu, M. \& Srinivas, P. (2009). Production of $\alpha$-amylase under solid-state fermentation utilizing coffee waste. J. Chem. Technol. Biotechnol., Vol. 84, No. 8, (August 2009), pp. 1246-1249, ISSN 1097-4660

Narang, S. \& Satyanarayana, T. (2001). Thermostable a-amylase production by an extreme thermophile Bacillus thermooleovorans. Letters in Applied Microbiology, Vol. 32, No. 1, (January 2001), pp. 31-35, ISSN 1472-765X

Obi, S. \& Odibo, F. (1984). Some properties of a highly thermostable $\alpha$-Amylase from a Thermoactinomyces sp. Can. J. Microbiol., Vol. 30, No. 6, (June 1984), pp. 780-785, ISSN 1480-3275

Okano, K., Zhang, O., Shinkawa, S., Yoshida, S., Tanaka, T., Fukuda, H. \& Kondo, A. (2009). Efficient Production of Optically Pure D-Lactic Acid from Raw Corn Starch by Using a Genetically Modified L-Lactate Dehydrogenase Gene-Deficient and $\alpha$-AmylaseSecreting Lactobacillus plantarum Strain. Appl. Environ. Microbiol., Vol. 75, No. 2, (January 2009), pp. 462-467, ISSN 098-5336

Olesen, T. (1991). Antistaling process and agent. Patent application, In: European Patent Application no. EP19900915100, April 2012, Available from: <http://www.freepatentsonline.com/EP0494233.html >

Omar, N., Abou-Dobara, M. \& El-Sayed, A. (2011). Studies on amylase produced by some actinomycetes, Lambert, Academic publishing ISBN 9783847334361, Germany

Pandey, A., Nigam, P., Soccol, C., Soccol, V., Singh, D. \& Mohan, R. (2000). Advances in microbial amylases. Biotechnol. Appl. Biochem., Vol. 31, No. 2, (April 2000), pp. 135-152, ISSN 1470-8744 
Petruccioli, M. \& Federici, R.G. (1992). A note on the production of extracellular hydrolytic enzymes by yeast-like fungi and related microorgnisms. Ann. Microbiol. Enzimol., Vol. 42, No.1 , pp. 81-86, ISSN 0003-4649

Prakash, O. \& Jaiswal, N. (2010). $\alpha$-Amylase: An Ideal Representative of Thermostable Enzymes. Appl Biochem Biotechnol., Vol. 160, No. 8, (April 2010), pp. 2401-2414, ISSN 1559-0291

Primarini, D. \& Ohta, Y. (2000). Some enzyme properties of raw starch digesting amylases from Streptomyces sp. no. 4. Starch/Starke, Vol. 52, No. 1, (January 2000), pp. 28-32, ISSN 1521-379X

Ratanakhanokchai, K., Kaneko, J., Kamio, Y. \& Izaki, K. (1992). Purification and properties of a maltotetraose and maltotriose producing amylase from Chloroflexus aurantiacus. Appl. Environ. Microbiol. Vol. 58, No. 8, (August 1992), pp. 2490-2494, ISSN 1098-5336

Rauscher, E. (1984). Determination of the degradation products maltose and glucose. In: Methods of enzymatic analysis, H. Bermeyer (Ed.), pp. (890-894), Weiheim, ISBN 3527255982, Verleg Chemie

Rhodes, C., Strasser, J. \& Friedberg, F. (1987). Sequence of an active fragment of Bacillus polymyxa $\beta$-amylase. Nucleic Acids Res., Vol. 15, No. 9, (May 1987), pp. 3934, ISSN 13624962

Riisgaard, S. (1990). The enzyme industry and modern biotechnology. In: Proceedings of the Fifth European Congress on Biotechnology, Vol. 1, C. Christiansen, L. Munck, J. Villadsen (Ed.), pp. (31-40), ISBN 8716106172, Munksgaard, Copenhagen.

Robyt, J.F. \& Whelan, W.J. (1972). Reducing value methods for maltodextrins: chain length dependence of alkaline 3,5-dinitrosalisylate and chain length independence of alkaline copper. Anal. Biochem., Vol. 45, No. 2, (February 1972), pp. 510-516, ISSN 0003-2697

Robyt, J.F. (1998). Essentials of Carbohydrate Chemistry, Springer, ISBN 0-387-94951-8, New York, USA.

Russell, J.B. (1984). Factors influencing competition and composition of the rumen bacterial flora. In: Herbivore nutrition in the subtropics and tropics. F.M.C. Gilchrist and R.I. Mackie (Ed.), pp. (313-345), The Science Press, ISBN 0907997031, Craighall, South Africa

Ryan, S.M., Fitzgerald, G.F. \& Van Sinderen, D. (2006). Screening for and identification of starch-, amylopectin-, and pullulan-degrading activities in Bifidobacterial strains. Appl. Environ. Microbiol., Vol. 72, No. 8, (August 2006), pp. 5289-5296, ISSN 1098-5336

Sahlstrom, S. \& Brathen, E. (1997). Effects of enzyme preparations for baking, mixing time and resting time on bread quality and bread staling. Food Chem., Vol. 58, No. 1, (January 1997), pp. 75-80, ISSN 0308-8146

Sambrook, J., Fritsch, E.F. \& Maniatis, T. (1989). Molecular cloning: a laboratory manual, 2nd ed. N. Harbor (Ed.), Cold Spring Harbor Laboratory Press, ISBN 0879693096, New York

Santamaria, R.I., Del Rio, G., Saab, G., Rodriguez, M.E., Soberön, X. and Loöpez-Munguia, A. (1999). Alcoholysis reactions from starch with $\alpha$-amylases. FEBS Letters, Vol. 452, No. 3, (June 1999), pp. 346-350, ISSN 0014-5793

Satoh, E., Uchimura, T., Kudo, T. \& Komagata, K. (1997). Purification, characterization, and nucleotide sequence of an intracellular maltotrioseproducing $\alpha$-amylase from 
Streptococcus bovis 148. Appl. Environ. Microbiol., Vol. 63, No. 12, (December 1997), pp. 4941-4944, ISSN 1098-5336

Saxena, R.K., Dutt, K., Agarwal, L. \& Nayyar, P. (2007). A highly thermostable and alkaline amylase from a Bacillus sp. PNS. Biores. Technol., Vol. 98, No. 2, (January 2007), pp. 260265, ISSN 0960-8524

Schäfer, T., Duffner, F. and Borchert, T.V. (2000). Extremophilic enzymes in industry: screening, protein engineering and application, Proceedings of Third International Congress on Extremophiles, Hamburg, Germany, 3-7 September 2000.

Shental-Bechor, D. \& Levy, Y. (2009). Folding of glycoproteins: toward understanding the biophysics of the glycosylation code. Current Opinion in Structural Biology, Vol. 19, No. 5, (October 2009), pp. 524-533, ISSN 0959-440X

Shigechi, H., Koh, J., Fujita, Y., Matsumoto, T., Bito, Y., Ueda, M., Satoh, E., Fukuda, H. \& Kondo, A. (2004). Direct Production of Ethanol from Raw Corn Starch via Fermentation by Use of a Novel Surface-Engineered Yeast Strain Codisplaying Glucoamylase and $\alpha$ Amylase. Appl. Environ. Microbiol., Vol. 70, No. 8, (August 2004), pp. 5037-5040, ISSN 098-5336

Shimizu, M., Kanno, M., Tamura, M. \& Suckane, M. (1978). purification and some properties of a novel $\alpha$-Amylase produced by a strain of Thermoactinomyces vulgaris. Agric. Biol. Chem., Vol. 42, No. 9, (September 1978), pp. 1681-1688, ISSN 1881-1280

Shinke, R., Nishira, H. \& Mugibayashi, N. (1974). Isolation of, B-amylase producing microorganisms. Agric. Biol. Chem., Vol. 38, No. 3, (March 1974), pp. 665- 666, ISSN 18811280

Siggens, K. (1987). Molecular cloning and characterization of the B-amylase gene from Bacillus circulans. Mol. Microbiol. Vol. 1, No.3, (November 1987), pp. 86-91, ISSN 13652958

Sills, A., Sauder, M. \& Stewart, G. (1984). Isolation and characterization of the amylolytic system of Schwanniomyces castelli . J Inst Brew., Vol. 90,pp. 311-314, ISSN 0046-9750

Smith, A.M. (1999). Making starch. Curr. Opin. Plant Biol., Vol. 2, No. 6, (December 1999), pp. 223-229, ISSN 1369-5266

Somers, W., Lojenja, A.K., Bonte, A., Rozie, H., Visser, J., Rombouts, F. \& Riet, V. (1995). Isolation of $\alpha$-amylase on crosslinked starch. Enzyme and Microb. Technol., Vol. 17, No. 1, (January 1995), pp. 56-62, ISSN 0141-0229

Speckmann, H., Kottwitz, B., Nitsch, C. \& Maurer, K.H. (2001). Detergents containing amylase and protease, In: Patent Application no. US6380147B1, April 2012, Available from:

$<$ http://www.google.com.eg/patents?hl=ar\&lr=\&vid=USPAT6380147\&id=jd8KAAAAEB $\mathrm{AJ} \& \mathrm{oi}=\mathrm{fnd} \& \mathrm{dq}=$ Detergents+containing + amylase + and + protease \& printsec $=$ abstract $\# \mathrm{v}=\mathrm{O}$ epage\&q=Detergents $\% 20$ containing $\% 20$ amylase $\% 20$ and $\% 20$ protease $\& \mathrm{f}=$ false $>$

Spendler, T. \& Jørgensen, O. (1997). Use of a branching enzyme in baking, In: Patent Application no. WO97/41736, April 2012, Available from $<$ http://www.wipo.int/patentscope/search/en/detail.jsf?docId=WO1997041736\&recNum $=1 \&$ maxRec $=\&$ office $=\&$ prevFilter $=\&$ sortOption $=\&$ queryString $=\&$ tab $=$ PCT + Biblio $>$ 
Srivastava, R. (1984). Studies on extracellular and intracellular purified amylases from a thermophilic Bacillus stearothermophilus. Enzyme Microb Technol., Vol. 6, No. 9, (September 1984), pp. 426-422, ISSN 0141-0229

Strokopytov, B., Knegtel, R.M.A., Penninga, D., Roozeboom, H.J., Kalk, K.H., Dijkhuizen, L. and Dijkstra, B.W. (1996). Structure of cyclodextrin glycosyltransferase complexed with a maltononaose inhibitor at $2.6 \mathrm{~A}^{\circ}$ resolution. Implications for product specificity. Biochemistry. Vol. 35, No. 13, (April 1996), pp. 4241-4249, ISSN 1520-4995

Sun H., Zhao, P., Ge, X., Xia, Y., Hao, Z., Liu, J. \& Peng, M. (2010). Recent Advances in Microbial Raw Starch Degrading Enzymes. Appl. Biochem. Biotechnol., Vol. 160, No. 4, (February 2010), pp. 988-1003, ISSN 1559-0291

Sunna, A., Moracci, M., Rossi, M. \& Antranikian, G. (1997). Glycosyl hydrolases from hyperthermophiles. Extremophiles, Vol. 1, No. 1, (February 1997), pp. 2-13, ISSN 14334909

Svensson B., Jensen M., Mori H., Bak-Jensen K., Bonsager B., Nielsen P., Kramhøft B., Praetorius-Ibba M., Nohr J., Juge N., Greffe L., Williamson G. \& Driguez H. (2002). Fascinating facets of function and structure of amylolytic enzymes of glycoside hydrolase family 13. Biologia Bratislava, Vol. 57, Suppl. 11,pp. 5-19, ISSN 0006-3088

Svensson, B. \& Sogaard, M. (1993). Mutational analysis of glycosylase function. J. Biotechnol. Vol. 29, No. 1, (May 1994), pp. 1-37, ISSN 0168-1656

Svensson, B. (1994). Protein engineering in the $\alpha$-amylase family: catalytic mechanism, substrate specificity, and stability. Plant Mol. Biol., Vol. 25, No. 2, (May 1994), pp. 141157, ISSN 1573-5028

Takasaki, Y. (1976). Purification and enzymatic properties of $\beta$ - amylase and pullulanase from Bacillus cereus var. mycoides. Agric. Biol. Chem., Vol. 40, No. 8, (August 1974), pp. 1523-1530, ISSN 1881-1280

Thompson, D.B. (2000). On the non-random nature of amylopectin branching. Carbohydrate Polymers, Vol. 43, No. 3, (November 2000), pp. 223-239, ISSN 0144-8617

Tonkova, A., (2006). Microbial starch converting enzymes of the $\alpha$-Amylase family. In: Microbial Biotechnology in Horticulture, R.C. Ray \& O.P. wards (Ed.), pp. (421-472), , Science Publishers, Enfield, ISBN 9781578084173, New Hampshire, USA

Tuohy, M. \& Coughlan, M. (1992). Production of thermostable xylan degrading enzymes by Talaromyces emersonii. Bioresource Technol., Vol. 39, No. 2, (February 1992), pp. 131-137, ISSN 0960-8524

Uguru, G., Akinyanju, J. \& Sani. A. (1997). The use of sorghum for thermostable amylase production from Thermoactinomyces thalpophilus. Letters in Applied Microbiology., Vol. 25, No. 1, (July 1997), pp. 13-16, ISSN 1472-765X

Uitdehaag, J., Mosi, R., Kalk, K., van der Veen, B., Dijkhuizen, L., Withers, S. \& Dijkstra, B. (1999). X-ray structures along the reaction pathway of cyclodextrin glycosyltransferase elucidate catalysis in the $\alpha$-amylase family. Nat. Struct. Biol., Vol. 6, No. 5, (May 1999), pp. 432-436, ISSN 1545-9985

Van Dam, H. \& Hille, J. (1992). Yeast and enzymes in bread making. Cereal Foods World, Vol. 37, No. 5, (September 1992), pp. 245-252, ISSN 0146-6283 
Vigal, T., Gil, J., Daza, A., Garcia-Gonzales, M. \& Martin, J.F. (1991). Cloning, characterization and of an $\alpha$-amylase gene from Streptomyces griseus IMRU3570. Mol. Gen. Genet., Vol. 225, No. 2, (February 1991), pp. 278-288, ISSN 1432-1874

Vihinen, M. \& Mantsala, P. (1989). Microbial amylolytic enzymes. Crit Rev Biochem Mol Biol., Vol. 24, No. 4, (April 1989), pp. 329-418, ISSN 1549-7798

Virolle, M., Long, C., Chang, S. \& Bibb, M. (1988). Cloning, characterization and regulation of an $\alpha$-amylase gene from Streptomyces venezuelae. Gene, Vol. 74, No. 2, (December 1988), pp. 321-334, ISSN 0378-1119

Wang, J.P., Mason, J.C. \& Broda, P. (1993). Xylanases from Streptomyces cyaneus: their production, purification and characterization. J. Gen. Micrbiol., Vol. 139, No. 9, (September 1993), pp. 1987-1993, ISSN 0022-1287

Wang, J.P., Zeng, A.W., Liu, Z. \& Yuan, X.G. (2006). Kinetics of glucoamylase hydrolysis of corn starch. J. Chem. Techno. and Biotechno., Vol. 81, No. 5, (May 2006), pp. 727-729, ISSN $1097-4660$

Wang, Y.W. \& Wang, Y. (1990) Study on nutrient physiology of some species of Ganoderma. Edible Fungi of China, Vol. 9, No. 5, (September 1990), pp. 7-10, ISSN 1003-8310

Wang, Y.W., Nema, S. \& Teagarden, D. (2010). Protein aggregation Pathways and influencing factors. Int. J. Pharm., Vol. 390, No. 2, (May 2010), pp. 89-99, ISSN 0378-5173

Wardi, A. \& Michos, G. (1972). Alcian blue staining of glycoproteins in acrylamide disc electrophoresis. Anal. Biochem., Vol. 49, No. 2, (October 1972), pp. 607-609, ISSN $0003-$ 2697

Whistler, R.L. \& Daniel, J.R. (1985). Carbohydrates, In: Food chemistry, O.R. Fennema, (Ed.), pp. (69-137), Marcel Dekker, ISBN 0-87055-504-9, New York, USA

Whitehead, T.R. \& Cotta, M.A. (1995). Identification of intracellular amylase activity in Streptococcus bovis and Streptococcus salivarius. Curr. Microbiol., Vol. 30, No. 3, (March 1995), pp. 143-148, ISSN 1432-0991

Wolfenden, R., Lu, X. \& Young, G. (1998). Spontaneous hydrolysis of glycosides. J. Am. Chem. Soc., Vol. 120, No. 27, (July 1998), pp. 6814-6815, ISSN 1520-5126

Yamamoto, T. (1988). Bacterial a-amylase (liquefying- and saccharifying types) of Bacillus subtilis and related bacteria. In: Handbook of amylases and related enzymes. The amylase research society of Japan (Ed.), pp. (40-45), Pergamon Press, ISBN 0080361412, Oxford

Yamane, K., Yamaguchi, K \& Maruo, B. (1973). Purification and properties of a crossreacting material related to $\alpha$-amylase and biochemical comparison with parental $\alpha$ amylase. Biochim Biophys Acta., Vol. 298, No. 2, (March 1973), pp. 295-323, ISSN 00052736

Zare-Maivan, H. \& Shearer, C.A. (1988). Extracellular enzyme production and cell wall degradation by freshwater lignicolous fungi. Mycology, Vol. 80, No. 3, (May 1988), pp. 365-375, ISSN 00275514

Zeikus, J. (1979). Thermophilic bacteria: ecology, physiology, and technology. Enzyme Microb. Technol., Vol. 1, No. 4, (October 1979), pp. 243-251, ISSN 0141-0229 
Zhu, F., Corke, H. \& Bertoft, E. (2011).Amylopectin internal molecular structure in relation to physical properties of sweetpotato starch. Carbohydrate Polymers, Vol. 84, No. 3, (March 2011), pp. 907-918, ISSN 0144-8617

Zobel, H.F. (1992). Starch granule structure, In: Developments in Carbohydrate chemistry, R. J. Alexander \& H.F. Zobel (Ed.), pp. (1-36), American association of cereal chemistry, ISBN 0913250767, Minnesota, USA. 